"Effective regional infrastructure delivery in Africa: an analysis of the financial skills of the technical staff"

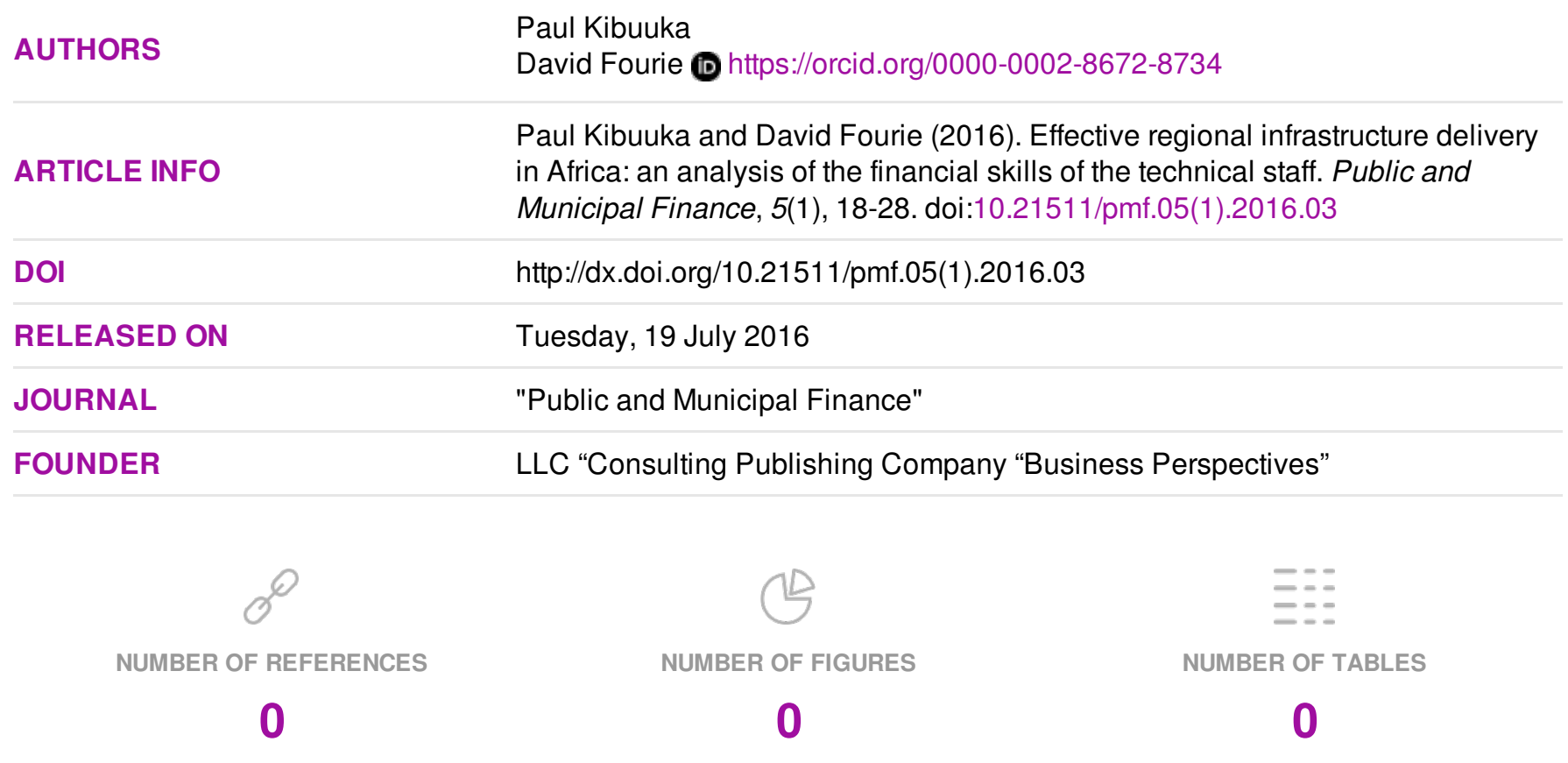

(C) The author(s) 2023. This publication is an open access article. 
Paul Kibuuka (South Africa), David Fourie (South Africa)

\title{
Effective regional infrastructure delivery in Africa: an analysis of the financial skills of the technical staff
}

\begin{abstract}
During the last fifteen years, it has become apparent that capacity building is an important ingredient for sustainable development. In this regard, governments in Africa rank capacity building for infrastructure delivery amongst the top priorities for promoting sustainable development.

A large share of Africa's infrastructure is domestically financed, with the central government budget being the main driver of infrastructure investment. It is, therefore, important to strengthen the finance and technical capacity of public sector officials to effectively manage the preparation, structuring, implementation and operations and maintenance of infrastructure.

In the quest to improve the infrastructure delivery capacity of public sector officials, this dip stick survey has assessed and highlighted gaps in terms of limited working knowledge of financial instruments, products and services such as viability gap finance and partial risk guarantees, as well as different financing models including fixed and floating interest rate borrowing from DFIs. All officials interviewed confirmed the importance of prioritizing finance training in the areas of selection, preparation and appraisal of investment projects.
\end{abstract}

Keywords: infrastructure development, reform agendas, sustainable development, capacity development, funding requirements.

JEL Classification: H10, H57, M48.

\section{Introduction}

The African continent has experienced unprecedented economic growth over the last two decades. This growth has been a result of improved governance, progressive macroeconomic policies and favorable commodity prices on the world markets. On the supply side, African countries have experienced a surge in the demand for energy, skilled human resources, information and communication technology in addition to infrastructure development in order to sustain the growth. A number of programs have been initiated by the African Union and the regional economic communities to address the developmental gaps, advance regional integration and accelerate growth.

Since recovery from the 2007/08 economic crisis, the global economy again registered slowing economic growth from the beginning of 2014 brought about by low global demand, depressed commodity prices, slowing Chinese economy, high market volatility and geopolitical tensions. These aspects have had macroeconomic contagion on developing and emerging markets in Africa resulting in lower than expected growth in 2015 due to declining government revenues and capital flows, increased budget and current account deficits. On 16 December 2015 the US Federal Reserve Bank increased interest rates by $0.25 \%$ after a nine year period of near zero interest rates. The World

(C) Paul Kibuuka, David Fourie, 2016.

Paul Kibuuka, D.Phil (Economic Demography), Associate Professor of Economics and Development Finance, Bureau of Market Research, College of Economics and Management Sciences, University of South Africa, Pretoria, South Africa.

David Fourie, D.Phil (Public Administration), Professor in Public Administration, School of Public Management and Administration, Faculty of Economics and Management Sciences, University of Pretoria, Pretoria, South Africa.
Bank (2015) predicted that there is a risk that raise may result in capital flows to developing countries shrinking by between 0.8 and 1.8 percentage points of GDP. In order to turn around this situation, a number of governments in Africa are focusing on putting in place competitive fiscal, monetary and economic policies to attract and retain capital flows and foreign direct investment through improved infrastructure, energy supply and appropriate skills development programs.

The method of mixed methods research formed the foundational construct for this pragmatic analysis through the combination of quantitative and qualitative approaches. This approach presented a framework for analysis to understand the finance skills required for technical staff in the public sector functioning in the delivery of infrastructure in Africa. The survey targeted a sample of officials in go-vernment departments, parastatals and regional multilateral institutions in East, Central and Southern Africa that are responsible for the detailed planning and scoping, preparation, implementation, and operations and maintenance of infrastructure in 3 corridors included within the Priority Action Plan under the African Union Sanctioned Program for Infrastructure Development in Africa (PIDA). The overall goal of PIDA is to promote socioeconomic development and poverty reduction in Africa through improved access to integrated regional and continental infrastructure network and services.

\section{Review of the related literature}

1.1. Contextualization of project finance. The International Project Finance Association (IPFA), as quoted by The United Nations Capital Development Fund, (2014), defines project finance "as the financing of long-term infrastructure, industrial projects 
and public services based upon a non-recourse or limited recourse financial structure where project debt and equity used to finance the project are paid back from the cash flow generated by the project".

The concept of public finance, on the other hand, deals with the budgeting techniques of the income and expenditures of a public sector organization, normally government or federal organization. Public finance is also termed as government finance and it is an important sector of finance and economics (Finance Maps of World, 2015).

The Department for International Development (DFID) (2009) indicated that strong Public Financial Management (PFM) capacity and systems are essential to improved service delivery, poverty reduction and to achievement of the Millennium Development Goals (MDGs). Effective PFM capacity and systems maximize financial efficiency, improve transparency and accountability, and, in theory, will contribute to long-term economic success. Activities range from the preparation and fulfilment of the budget cycle, budget oversight and control, taxing and debt management and procurement, to resource allocation and income distribution, and are increasingly seen as a set of inter-related sub systems (and organizational and political cultures), rather than a standalone activity.

1.2. Effective Public Financial Management (PFM) systems are required to maximize the efficient use of resources, create the highest level of transparency and accountability in government finances and to ensure long-term economic success (Fourie, 2012). Recent literature has highlighted the importance of sound PFM systems to service delivery, poverty reduction and the achievement of the Millennium Development Goals (MDGs) (DFID, 2009).

\subsection{Training and development with reference to}

PFM. The Acorys Academy (2015) postulated that a PFM training course should aim to provide participants with an understanding of Public Finance Management (PFM) in all its aspects. The course should focus on Public Finance Management in-depth and build up knowledge on all aspects of PFM step by step, highlighting the inter-linkages between the different elements. This will enable the participants to become fully acquainted with the various aspects of PFM and to gain insight into how to apply the acquired knowledge in PFM to the reform agendas in their own countries. The training program should emphasize the three main objectives of PFM: 1) promoting macroeconomic stability by achieving aggregate fiscal discipline; 2) enabling that policy priorities are implemented in an effective way (allocative efficiency); and 3) contributing to an efficient implementation of government services (operational efficiency). The training program should also have a practical and interactive character. This is in line with the objective to share knowledge and strengthen the cooperation between the civil servants of the participating countries.

1.4. Infrastructure project cycle. According to the World Economic Forum (2014), the management of a transnational infrastructure program faces many of the same difficulties as managing any large infrastructure program. Requirements for meeting the budget, quality standards and schedule are: capital expenditure needs to be minimized; the design of the program should aim to optimize value; rigorous risk management must be applied; contracting strategy and procurement need to be refined; and scarce resources must be secured. This implies that, to effectively plan, fund, implement and operate projects, public sector officials require a mix of both technical and public and project financial skills. The technical skills are acquired through training at universities and technikons (technical colleges in the South African context) followed by experiential learning which is a requirement for registration with professional engineering bodies. The acquisition of finance skills is the main objective of this analysis.

The technical officials act as project managers, consultants and advisors to oversee the selection and preparation of complex infrastructure public private sector partnership contracts through public sector comparators and value for money analysis. The credit risk pricing models are utilized to determine pricing of loan products, lending and investment management processes and provide input into the appraisal and portfolio management and are part and parcel of efficient project management. Funding of some of the contracts involves lead arranging and syndication of financial structures and ensuring that the lead arranger plays the critical roles of drawing down, effecting interest charges and repayments. In order to manage the funding phases of the projects sustainably, it is important for the officials to fully comprehend project finance with clear understanding of the application of on balance sheet and off balance sheet finance arrangements. Measures used by investors and lenders are major inputs to the project finance model and the term sheet based on which the project funding agreement is developed.

The Development Bank of Southern Africa (DBSA) (2004) pointed out that the term project finance is often interpreted incorrectly as the generic financing of a project. However, project financing is a specialized funding structure that relies on the future cash flow of a project as a primary source of repayment, and holds the project's assets, rights and interests as collateral security. It is also referred to as non- or limited recourse finance, where lenders have no or limited recourse to the sponsors or shareholders of the project company for repayment of the loan. 
From a private sector perspective, a company that wants to implement a new project without encumbering its balance sheet could consider establishing a special purpose project company that implements the project and raises the funding. In doing so, the corporate balance sheet is protected against the risks associated with a large project. The project company is legally independent from its shareholders. This provides a safeguard for the project in the event of failing shareholders dragging an otherwise healthy project into distress or vice versa.

As indicated in Figure 1, financial skills are an integral part of the effective implementation of the infrastructure project cycle by technical experts, though these aspects seldom form part of the core modules of their technical qualification. Engineers leading cross boarder or large infrastructure projects are required to reach and implement agreements on sharing risks, costs and benefits while optimizing financing structures across countries with different economic capacities. The costs include those for project preparation, construction work and operating the facility throughout the life cycle. The project managers are expected to lower the cost of capital by keeping abreast with all the conditions required for raising funding from local and international development finance institutions, sovereign wealth funds, capital markets and export credit agencies. The priority is to capacitate the officials to select the correct financial delivery structure and to source funding at a cost that will yield the highest overall benefits.

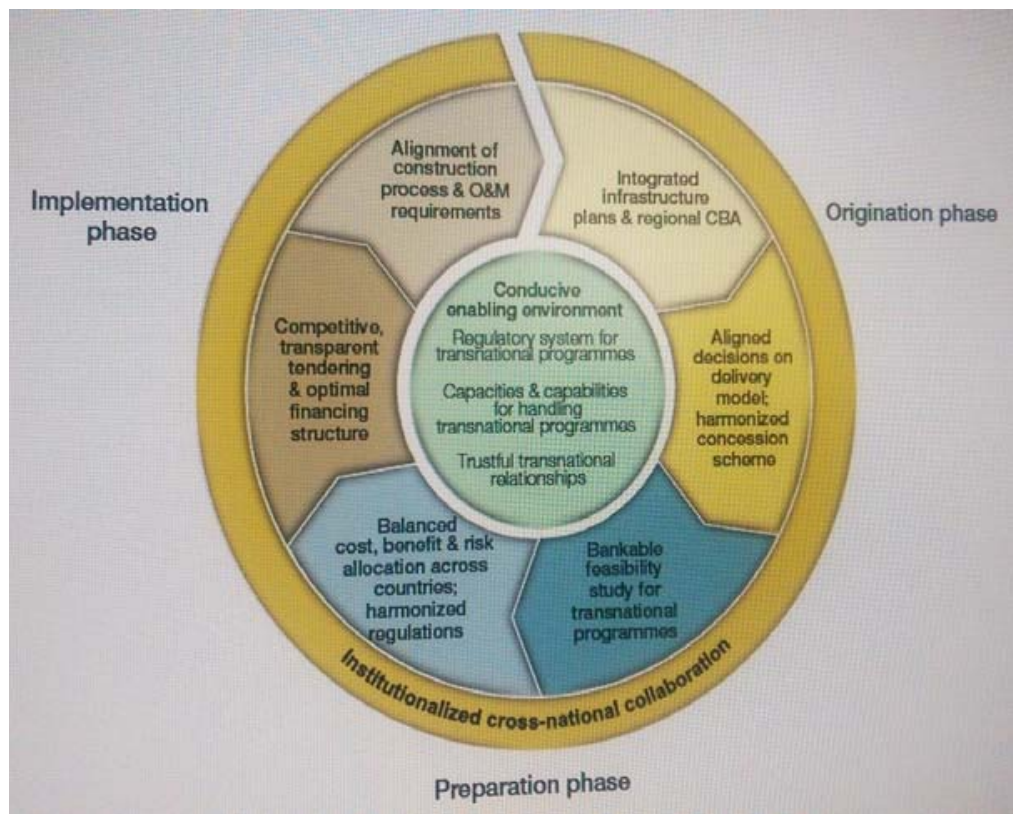

Source: World Economic Forum, African Strategic infrastructure Initiative 2014.

Fig. 1. Best practice framework for managing transnational infrastructure programs

\section{Current infrastructure backlogs in Africa}

One of the latent, but, yet, the most significant infrastructure delivery challenge faced by the continent is infrastructure operations and maintenance. Asset maintenance needs to be understood as an investment in asset preservation. Researchers have expressed concerns about the enormous magnitude of new infrastructure developed during the last decade and placed into the hands of authorities that do not have adequate capacity to operate and maintain them(DBSA Development Fund, 2008). The World Bank (2010) estimated the overall infrastructure rehabilitation backlog in Africa to be equivalent to $30 \%$. The highest concentration of the backlog is in the road sector $(42 \%)$ followed by railways $(40 \%)$, water and sanitation (35\%) and electricity (25\%). In order to address this aspect, governments need to strengthen annual budgeting, operations and main- tenance planning, execution, monitoring and capacity building.

The research conducted by the International Bank for Reconstruction and Development (IBRD, 2010) showed that infrastructure has been responsible for more than half of Africa's recent improved growth performance and has the potential to contribute even more in the future. Africa's infrastructure networks increasingly lag behind those of other developing countries and are characterized by missing regional links and stagnant household access. Africa's difficult economic geography presents a particular challenge for the region's infrastructure development. Africa's infrastructure services are twice as expensive as elsewhere, reflecting both economies of scale in production and high profit margins caused by lack of competition. Power (energy) is, by far, Africa's largest infrastructure challenge, with 30 
countries facing regular power shortages and many paying high premiums for emergency power.

The infrastructure challenge varies greatly by country type - fragile states face an impossible burden and resource-rich countries lag, despite their wealth. A large share of Africa's infrastructure is domestically financed, with the central government budget being the main driver of infrastructure investment (IBRD, 2010). Africa's institutional, regulatory, and administrative reforms are only halfway along, but they are already proving their effect on operational efficiency. For example, meeting Africa's infrastructure needs calls for a very substantial program of infrastructure investment and maintenance involving the development of an additional 7,000 megawatts a year of new power generation capacity (about half through multipurpose water storage schemes). It requires enabling regional power trade by laying 22,000 megawatts of cross-border transmission lines and completing the intraregional fiberoptic backbone network and continental submarine cable loop. It is important to interconnect capitals, ports, border crossings, and secondary cities with a good quality road network and to provide all-season road access to Africa's high-value agricultural land. The target should be to more than double Africa's irrigated area and to strive at meeting the MDGs for water and sanitation. Raise household electrification rates by 10 percentage points and increase global systems mobile voice signal and public access broad band to 100 percent of the population (IBRD, 2010).

\section{Africa infrastructure funding requirements}

The Ernest and Young report (2014) on large infrastructure projects in Africa indicated that of the 196 active projects in their database, 141 or $72 \%$ are still in the conceptual, planning or preimplementation phase. In other words, only $28 \%$ of projects are being implemented. Despite being recognized as essential for the growth and competitiveness of a country, many large infrastructure projects are simply not getting off the ground. Lack of funding is often cited as the biggest reason behind Africa's infrastructure gap. According to the World Bank (2010), Africa needs to spend about \$93bn annually until 2020 to bridge its infrastructure gap. As daunting as that sounds, half of this amount is already being financed by African governments, multilateral and bilateral sources of finance and official development assistance (ODA). Europe is the biggest ODA financier in Africa, funding more than $\$ 4 \mathrm{bn}$ annually to the continent.

At the same time, new sources of financing are surfacing. For example, African governments have increased their own investments in infrastructure and, in addition, regional development banks are playing an increasingly important role (E\&Y, 2014). The African Development Bank signed a co-financing deal with China worth $\$ 2$ bn for infrastructure and industrial development. There has also been an increase in intra-African investment showing an improvement in regional integration. Crucially, as the second most attractive investment destination in the world, the continent has become an attractive market to private investors. In 2012, $\$ 12.8 \mathrm{bn}$ was invested by the private sector into new or expanded infrastructure projects in Africa. All 196 infrastructure projects in the E\&Y database have some form of financing.

The figures and feedback presented by the Programme for Infrastructure Development in Africa (PIDA) (2015) portray similar trends. They indicate that key challenges for regional infrastructure development in Africa include: lack of sound bankable projects; inadequate early stage investment for project preparation, and lack of skilled transaction advisers. Therefore, addressing the critical barriers of feasibility and bankability at the early and middle stages of the project cycle, especially at origination, are important pre-requisites for projects to achieve financial close.

The Development Bank of Southern Africa (2015) estimates the PIDA infrastructure funding needs for Africa to be in the region of $\$ 120 \mathrm{bn}$. The Ernest and Young Report (2014) emphasizes that, given a PIDA implementation price tag of US\$ 68 billion to 2020, and assuming a reduction of the project preparation bankability period to 3 years from a minimum of 7 years, the PIDA PAP 2020 will require US $\$ 2.5$ billion annually, for project preparation. This cost for PIDA project preparation is well beyond affordability of the public purse alone to meet without support from the private sector and development partners. Hence, the PIDA Service Delivery Mechanism by the African Union Commission (AUC) and the New Partnership for Africa's Development (NEPAD) Agency seeks to facilitate unblocking of project enabling environment and origination issues at national level of project sponsorship. The Infrastructure Consortium for Africa (ICA) assessment of Project Preparation Facilities (PPFs) indicates that projects at the early stages of the project preparation cycle lack support and where there is support, it is not systematically provided. Most PPFs, as main vehicles for project development, tend to focus on middle and downstream stages, where risk is relatively lower and better mitigated. At the national and regional level, there is a lack of capacity to develop such complex projects. This, coupled with an uncoordinated project planning process, undermines the develop- 
ment of these projects, especially at early stages. In this regard, and, in its role as the executing agency for PIDA Priority Action Projects (PAP) implementation, the NEPAD Agency, together with the key stakeholders in the PIDA process, came up with innovative mechanisms to address PIDA project preparation needs and other challenges. The Service Delivery Mechanism aims to facilitate access to technical assistance services, to address early stage project preparation issues and challenges. If the PIDA-PAP is to be a reality, concerted effort must be put in place to get projects that are still at the origination stage to roll through the project cycle to bankability.

\section{Infrastructure capacity building and delivery programs in Africa}

PIDA is bringing together and merging various continental infrastructure initiatives, such as the NEPAD Short Term Action Plan, the NEPAD Medium to Long Term Strategic Framework (MLTSF), and the AU Infrastructure Master Plan initiatives into one coherent program for the entire continent, covering all the four key sectors of Transport, Energy, Trans boundary Water, and Information and Communication Technology (ICT). PIDA has developed an infrastructure investment program (short, medium and long term) built around key priorities and which includes an implementation strategy, as well as a priority action plan. PIDA is the AU/NEPAD key planning/programming document guiding the continental infrastructure development agenda, policies, and investments priorities in Transport, Energy, ICT, and Transboundary Water sectors for 2011-2030. It also provides the much-needed framework for engagement with Africa's development partners willing to support regional and continental infrastructure. Capacity development is a key focus for NEPAD, as it cuts across and underpins all of the work of the agency. Through capacity building NEPAD is better able to achieve success in its programs and improve the living conditions of all African residents. The Capacity Development Program prioritizes the AU/NEPAD Capacity Development Strategic Framework (CDSF) through all its work, including through collaboration with academic institutions and other stakeholders. The NEPAD Capacity Development Initiative (CDI) has successfully managed to sensitize stakeholders about the Capacity Development Strategic Framework.

Aware of the capacity constraints in the continent to implement infrastructure programs, NEPAD has consistently developed capacity building delivery programs alongside each infrastructure program.
The Infrastructure Skills for Development program (IS4D) is delivering an on-the-job action learning program for key public sector African infrastructure professionals to instill them with improved project management skills and thereby accelerate progress at closing Africa's severe infrastructure gap.

\section{Sample selection of respondents for asses- sing finance skills training needs in Africa}

The selection is a non-probability purposive sample consisting of 18 technical middle, senior and chief director level public sector officials mainly in the areas of civil, electrical engineering (94\%) and transport economics $(6 \%)$ from government departments in seven different countries and multi lateral regional institutions in East, Central and Southern Africa. The sample is targeted to capture specific officials responsible for driving large scale Pan-Africa regional integration projects, thereby providing a feel of the existing capacity and the capacity needs of the team at the coal face of critical economic infrastructure delivery in the sub-region and the continent at large. The respondents perform different roles including infrastructure project managers, consultants and advisory services. They are involved in 3 corridor infrastructure projects included within the Priority Action Plan under the AU-sanctioned PIDA. These include:

- the North-South Power Transmission Corridor in East and Southern Africa, with a specific focus upon the Zambia-Tanzania-Kenya segment which will, eventually, connect Eastern Africa Power Pool to Southern Africa Power Pool;

- the Beira-Naçala Rail Corridor, with a specific focus upon two rail routes crossing Malawi and connecting inland countries to seaports in Mozambique;

- the Northern Multi-Modal Road/Rail Corridor originating in East Africa and extending into Central Africa, with a specific focus upon road segments into the interior that require upgrading, as well as a focus upon installation of a standard gauge railway that will eventually connect Uganda, DRC, Rwanda and South Sudan through Kenya to Mombasa port.

According to their job descriptions, based on Figure 1 , the officials are currently undertaking project origination and project preparation phases with a view to develop the projects up to the implementation phase. On a high level, the value chain will entail integrated development planning, conducting feasibility studies, developing technical reports, project business planning, structuring and sourcing funding, procurement, construction and operations and maintenance. 


\section{Data collection}

The research instrument (questionnaire) was designed to cover all major and critical demographic and finance training experiences, needs and objectives. The length of the questionnaire was structured in such a way that it is convenient to send and administer electronically in a period preferably not exceeding approximately 30 minutes of interviewing or completion time. The rating of opinions, feelings, expectations and experiences of the public sector officials with the following finance skills training and related activities was measured:

- Demographic aspects: depicting the respondents' names and gender, as reflected on their official identity document.

- Previous and current finance training needs: the data captured whether the respondent have previously studied finance or any related subject including the level and length of these studies.

- Employment track record: capturing the name of employer and current employment position.

- Working knowledge of different finance areas, products and services: the individual rating of the working knowledge of public finance management and specific financing instruments including equity, debt, sovereign guarantees, viability gap financing, development credits, partial risk guarantees, on balance sheeting lending and project cash-flow analysis including public finance ratios.

- Working knowledge of different finance models: the individual rating of the working knowledge of fixed and floating interest rate borrowing, state-owned enterprise borrowing, private sector credit extension, project linked and non-project linked grant funding, resource backed infrastructure finance, special purpose vehicles, public private partnerships and the social context of infrastructure delivery.

- Assessment of different finance training areas required to fulfil the goals of the current PIDA corridor project: expression by each respondent of the finance content areas that are critical training knowledge to assist in the fulfilment of the goals of the corridor project currently undertaken.
- Proposal for other special finance training areas required: providing insight in any special training area required for self-development and effective infrastructure project delivery.

The enquiry on finance training experiences, needs, objectives and preferences would allow the construction of a strategy document that may inform theoretical and on the job finance training course development, prioritization and funding for training providers and sponsors to support governments and multilateral agencies in fast tracking the development of a pipeline of critical skills for infrastructure delivery to promote regional integration in Africa.

\section{Analysis and presentation of results}

7.1. Demographic aspects. As indicated under section 6, the sample was composed of 18 respondents that are technical public sector officials involved in the execution of the PIDA Priority Action Plan Projects for East, Central and Southern Africa. The officials were selected targeting 3 from the Republic of Kenya, 3 from Zambia, 3 from Uganda, 1 from the Southern Sudan, 2 from Malawi, 2 from the Democratic Republic of Congo, 2 from Tanzania and 2 from the East African Community Headquarters in Arusha. The sample is relatively small, but, given the size of the institutions and the challenges of securing respondents, the data captured and figures presented provide a high-level indicative trend of the training needs landscape of the region as a whole.

7.2. Previous and current areas of study in the field of finance. As indicated in Figure 3, the majority of the officials (67\%) confirmed that they had not previously studied finance or any related courses. This would be a function of the fact that the majority (94\%) of the respondents are engineers with a civil and electrical academic background. It was also confirmed that the few members that have had exposure to training in finance (33\%) had acquired it either through studying Master's in business management, or as part of one of the undergraduate degree modules, and as related short courses undertaken post the engineering qualification. One of the respondents specifically stated that finance had been studied as a topic in engineering management at the university 15 years ago. 


\section{The proportion of respondents that have previously studied finance or a related course}

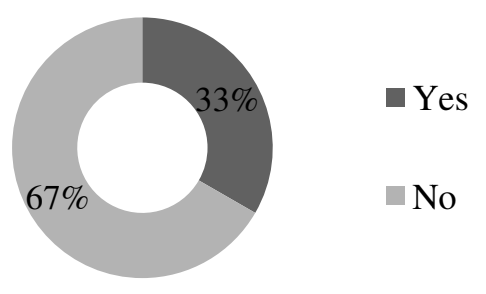

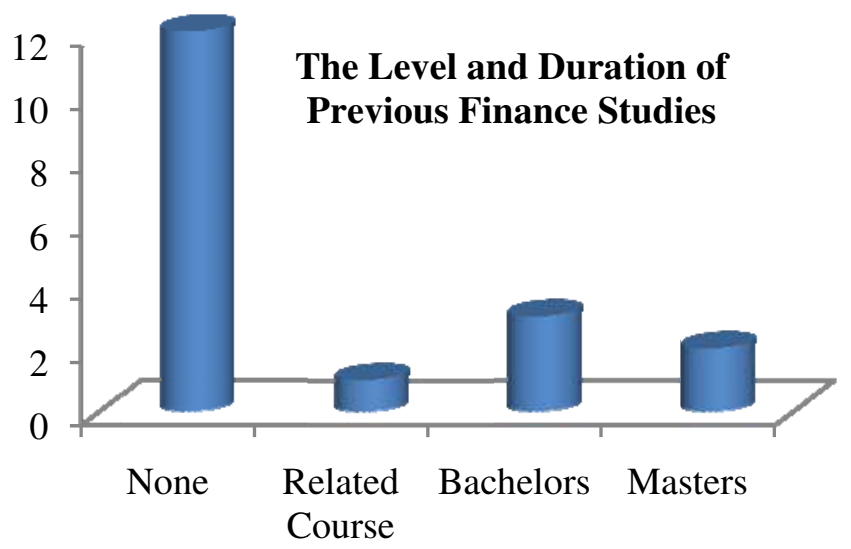

Fig. 2. Previous areas of study in finance and the duration

\subsection{Employment track record of the respon-} dents. The majority of the officials are practicing engineers (17) and one transport economist all employed by government departments, parastatals, utilities and the East African Community. Their designations range from assistant engineer infrastructure to Chief Engineer and economist in the departments of transport, roads, railways, energy and public works. Two of the senior engineers are consultants at the East African Community Secretariat headquarters in Arusha.

7.4. Working knowledge of public finance management. The concept of public finance is wide, in this context, it comprises the government budget, its revenue and expenditure, the borrowing program, as well as the overarching legislation, fiscal and monetary policies. The officials were expected to express views in terms of their exposure and understanding of the economic fundamentals that drive a country or region's investment performance in the areas of economic, social and institutional infrastructure development. In order to drive the infrastructure programs effectively, the officials rely on a number of funding sources. As indicated under section 4, the largest source in Africa is transfers from the fiscus which are spread out and presented in the government's medium term expenditure framework. In order to ensure continuous project implementation, these transfers should align with the tranches required to implement the different phases of the project cycle. In case of funding gaps alternative sources have got to be explored. As indicated in Figure 5 below, the majority of public sector officials $(78 \%)$ rated their working knowledge of public finance limited.

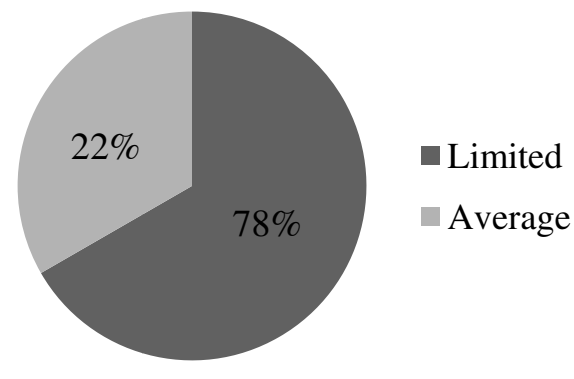

Fig. 3. Rating of working knowledge of public finance management

7.5. Working knowledge of different finance instruments, products and services. Knowledge of the different financing instruments, products and services is critical for efficient project structuring, risk management and maximization of return on investment. An efficient project structure lowers the cost of capital, reduces overheads and mitigates risk, thereby optimizing both the financial and social economic benefits of the projects. The questionnaire identified 8 important instruments, products and services for rating by the respondents on a three tier scale of limited, average and advanced. The results of the percentage distribution are indicated in the last row of Table 1 . None of the officials reported advanced working knowledge of any of the instruments, instead there was a preponderance of limited working knowledge with all of the instruments presented in the Table. The viability gap finance presented the most limited working knowledge for the officials. The instrument bridges the gap between what users of an infrastructure service can afford to pay and what is required to make the project commercially viable. 
Table 1. Rating of working knowledge of instruments, products and services

\begin{tabular}{|c|c|c|c|c|c|c|c|c|}
\hline & Equity & Debt & $\begin{array}{c}\text { Resource } \\
\text { backed finance }\end{array}$ & $\begin{array}{l}\text { Sovereign } \\
\text { loan } \\
\text { guarantees }\end{array}$ & $\begin{array}{l}\text { Viability gap } \\
\text { finance }\end{array}$ & $\begin{array}{l}\text { Development } \\
\text { crisis }\end{array}$ & $\begin{array}{l}\text { Partial risk } \\
\text { guarantees }\end{array}$ & $\begin{array}{l}\text { Cash flow analysis \& } \\
\text { public finance ratios }\end{array}$ \\
\hline Respondent 1 & Limited & Limited & Limited & Limited & Limited & Limited & Limited & Limited \\
\hline Respondent 2 & Average & Average & Limited & Average & Limited & Average & Average & Average \\
\hline Respondent 3 & Limited & Limited & Limited & Limited & Limited & Limited & Limited & Limited \\
\hline Respondent 4 & Limited & Limited & Average & Average & Limited & Limited & Limited & Limited \\
\hline Respondent 5 & Limited & Limited & Average & Average & Limited & Limited & Limited & Average \\
\hline Respondent 6 & Average & Average & Limited & Limited & Limited & Limited & Limited & Limited \\
\hline Respondent 7 & Limited & Limited & Limited & Limited & Limited & Limited & Limited & Limited \\
\hline Respondent 8 & Average & Average & Limited & Limited & Limited & Limited & Limited & Average \\
\hline Respondent 9 & Average & Average & Average & Limited & Limited & Average & Limited & Average \\
\hline Respondent 10 & Limited & Limited & Limited & Limited & Limited & Limited & Limited & Limited \\
\hline Respondent 11 & Average & Average & Average & Average & Average & Limited & Average & Average \\
\hline Respondent 12 & Average & Average & Average & Average & Average & Average & Average & Average \\
\hline Respondent 13 & Limited & Limited & Limited & Limited & Limited & Limited & Limited & Limited \\
\hline Respondent 14 & Limited & Limited & Limited & Limited & Limited & Limited & Limited & Limited \\
\hline Respondent 15 & Limited & Limited & Limited & Average & Limited & Limited & Limited & Limited \\
\hline Respondent 16 & Limited & Limited & Limited & Limited & Limited & Limited & Limited & Limited \\
\hline Respondent 17 & Limited & Limited & Limited & Limited & Limited & Limited & Limited & Limited \\
\hline Respondent 18 & Limited & Limited & Limited & Limited & Limited & Limited & Limited & Limited \\
\hline $\begin{array}{l}\% \text { Distribution of ranking } \\
\text { Limited: Average: Advanced }\end{array}$ & $67: 33: 0$ & 67:33:0 & 72:28:0 & 67:33:0 & 94:06:0 & 78:22:0 & 83:17:0 & 67:33:0 \\
\hline
\end{tabular}

7.6. Working knowledge of different finance models. The results of the feedback by officials regarding their working knowledge of finance models follow the same locus as that of the instruments, products and services reported above. The officials registered the highest percentage of limited working exposure to models of fixed and floating interest rate borrowing from DFIs. On the other hand, $6 \%$ of the respondents recorded advanced working knowledge of project and non-project linked grant funding models, as well as models for the structuring of public-private sector partnerships. It is notable in the last column of Table 2 that the most favorable results of working exposure to all the models are reflected under the public-private sector projects. This is an outcome of the extensive investment in PPP training courses for public officials by governments, development finance institutions and donor agencies over the last two decades coupled with opportunities for participation by the officials in the implementation of different PPP contracts for large infrastructure projects at a national and regional level in the continent. The success has resulted in the balance between limited and average exposure categories in addition to recording an advanced working knowledge in this area.

Table 2. Rating of working knowledge with finance models

\begin{tabular}{|l|c|c|c|c|c|c|}
\hline & $\begin{array}{c}\text { Fixed and floating } \\
\text { interest rate borrowing } \\
\text { from DFls }\end{array}$ & $\begin{array}{c}\text { State owned } \\
\text { enterprise funding }\end{array}$ & $\begin{array}{c}\text { Project and non- } \\
\text { project linked grant } \\
\text { funding }\end{array}$ & $\begin{array}{c}\text { Private sector } \\
\text { credit extension }\end{array}$ & $\begin{array}{c}\text { Resourced backed } \\
\text { infrastructure finance }\end{array}$ & $\begin{array}{c}\text { Structuring public } \\
\text { private sector projects }\end{array}$ \\
\hline Respondent 1 & Limited & Limited & Limited & Limited & Limited & Limited \\
\hline Respondent 2 & Limited & Average & Average & Limited & Limited & Limited \\
\hline Respondent 3 & Limited & Limited & Limited & Limited & Limited & Limited \\
\hline Respondent 4 & Limited & Limited & Average & Average & Average & Average \\
\hline Respondent 5 & Average & Limited & Average & Average & Limited & Average \\
\hline Respondent 6 & Limited & Limited & Limited & Limited & Average & Average \\
\hline Respondent 7 & Limited & Limited & Limited & Limited & Limited & Limited \\
\hline Respondent 8 & Average & Average & Limited & Average & Average & Limited \\
\hline Respondent 9 & Limited & Average & Average & Average & Average & Average \\
\hline Respondent 10 & Limited & Limited & Average & Limited & Limited & Average \\
\hline Respondent 11 & Average & Average & Advanced & Average & Limited & Advanced \\
\hline Respondent 12 & Average & Average & Average & Average & Average & Average \\
\hline Respondent 13 & Limited & Limited & Limited & Limited & Limited & Limited \\
\hline Respondent 14 & Limited & Limited & Limited & Limited & Limited & Average \\
\hline Respondent 15 & Average & Average & Average & Average & Average & Average \\
\hline Respondent 16 & Limited & Limited & Limited & Limited & Limited & Limited \\
\hline
\end{tabular}


Table 2 (cont.). Rating of working knowledge with finance models

\begin{tabular}{|l|c|c|c|c|c|c|}
\hline & $\begin{array}{c}\text { Fixed and floating } \\
\text { interest rate borrowing } \\
\text { from DFIs }\end{array}$ & $\begin{array}{c}\text { State owned } \\
\text { enterprise } \\
\text { funding }\end{array}$ & $\begin{array}{c}\text { Project and non- } \\
\text { project linked } \\
\text { grant funding }\end{array}$ & $\begin{array}{c}\text { Private sector } \\
\text { credit extension }\end{array}$ & $\begin{array}{c}\text { Resourced backed } \\
\text { infrastructure finance }\end{array}$ & $\begin{array}{c}\text { Structuring public } \\
\text { private sector } \\
\text { projects }\end{array}$ \\
\hline Respondent 17 & Limited & Limited & Limited & Limited & Limited & Limited \\
\hline Respondent 18 & Limited & Limited & Limited & Limited & Limited & Limited \\
\hline $\begin{array}{l}\text { \% Distribution of ranking } \\
\text { Limited:Average:Advanced }\end{array}$ & $72: 82: 0$ & $67: 33: 0$ & $55: 39: 6$ & $61: 39: 0$ & $67: 33: 0$ & $50: 44: 6$ \\
\hline
\end{tabular}

7.7. Finance training areas required by officials to fulfil the goals of their PIDA corridor projects. Under this section, the respondents were provided with several potential areas of training in finance and asked to indicate their preference in terms of assisting them to fulfill the goals of their individual PIDA corridor projects. As reflected in Table 3, all the officials (100\%) indicated the importance of increasing their technical capacity in the selection, preparation and appraisal of investment projects followed by the need for exposure in the social economic context of infrastructure delivery. This research finding supports data from the Development Bank of Southern Africa in Figure 2 which confirm that $95 \%$ of all the PIDA projects are still in concept and prefeasibility stage and will, therefore, require extensive capacity to move through technical report and business plan stages up to financial close. The lowest need by officials (67\%) was recorded in the area of DFI funding and expenditure for infrastructure development. This is plausible because most public private sector infrastructure deals on the continent have been lead arranged and syndicated by DFIs including the Africa Development Bank, the World Bank Group, the Development Bank of Southern Africa and the Industrial Development Corporation. Public sector officials in the different countries have had exposure to these finance institutions through participation in one or more of these transactions.
7.8. Proposals by officials for other special finance training areas required. The public sector officials having gone through the proposed finance training areas provided in the questionnaire were given a chance based on their current project management and advisory duties in the implementation of the PIDA priority action plan to identify any gaps and to propose extra areas not covered. These areas are not only potential input to curricula of further and higher education institutions of learning, but also short targeted courses designed by private training providers and academies of development finance institutions.

Table 4 presents a number of the special courses proposed by the officials including the engineering procurement contract (EPC) funding models, the build, operate and transfer (BOT) public private contracts, the China Exim Bank EPC contracts and public-private partnership concessions. The characteristics and legal framework of special purpose vehicles, the regulated asset base (RAB) model, the value for money analysis of public-private partnerships and the structuring of cross boarder donor funded projects. Output performance based road contracts and power stations funding models. Almost $45 \%$ of the respondents were fully satisfied with the training areas proposed in Tables 1 and 2.

Table 3. Choice of content areas to assist respondents in the achievement of project goals

\begin{tabular}{|c|c|c|c|c|c|c|c|c|c|c|}
\hline & $\begin{array}{c}\text { Social } \\
\text { economic } \\
\text { context of } \\
\text { infrastruc- } \\
\text { ture } \\
\text { delivery }\end{array}$ & $\begin{array}{l}\text { Selection } \\
\text { preparations } \\
\text { of debt and } \\
\text { equity for } \\
\text { infrastruc- } \\
\text { ture funding }\end{array}$ & $\begin{array}{l}\text { Sovereign, } \\
\text { corporate } \\
\text { and bank } \\
\text { guarantees }\end{array}$ & $\begin{array}{l}\text { Viability } \\
\text { gap } \\
\text { finance }\end{array}$ & $\begin{array}{l}\text { Project } \\
\text { finance } \\
\text { and } \\
\text { balance } \\
\text { sheet } \\
\text { lending } \\
\text { models }\end{array}$ & $\begin{array}{l}\text { Sources of } \\
\text { finance for } \\
\text { infrastruc- } \\
\text { ture devel- } \\
\text { opment }\end{array}$ & $\begin{array}{l}\text { DFI funding } \\
\text { and expendi- } \\
\text { ture for for } \\
\text { infrastruc- } \\
\text { ture devel- } \\
\text { opment }\end{array}$ & $\begin{array}{l}\text { Financing } \\
\text { products } \\
\text { and risk } \\
\text { mitigation } \\
\text { instruments }\end{array}$ & $\begin{array}{l}\text { Financing } \\
\text { products } \\
\text { and risk } \\
\text { mitigation } \\
\text { instruments }\end{array}$ & $\begin{array}{l}\text { Development } \\
\text { credits for } \\
\text { infrastructure } \\
\text { development }\end{array}$ \\
\hline Respondent 1 & $\sqrt{ }$ & $\sqrt{ }$ & $\sqrt{ }$ & $\sqrt{ }$ & $\sqrt{ }$ & $\sqrt{ }$ & $\sqrt{ }$ & $\sqrt{ }$ & $\sqrt{ }$ & $\sqrt{ }$ \\
\hline Respondent 2 & $\sqrt{ }$ & $\sqrt{ }$ & $\sqrt{ }$ & $\sqrt{ }$ & $\sqrt{ }$ & $\sqrt{ }$ & $x$ & $\times$ & $\sqrt{ }$ & $\sqrt{ }$ \\
\hline Respondent 3 & $\sqrt{ }$ & $\sqrt{ }$ & $x$ & $\sqrt{ }$ & $\sqrt{ }$ & $x$ & $\sqrt{ }$ & $x$ & $\sqrt{ }$ & $x$ \\
\hline Respondent 4 & $\sqrt{ }$ & $\sqrt{ }$ & $\sqrt{ }$ & $\sqrt{ }$ & $\times$ & $\sqrt{ }$ & $x$ & $\sqrt{ }$ & $\sqrt{ }$ & $x$ \\
\hline Respondent 5 & $\sqrt{ }$ & $\sqrt{ }$ & $\sqrt{ }$ & $\sqrt{ }$ & $\times$ & $\sqrt{ }$ & $\sqrt{ }$ & $x$ & $x$ & $\sqrt{ }$ \\
\hline Respondent 6 & $x$ & $\sqrt{ }$ & $\sqrt{ }$ & $\sqrt{ }$ & $x$ & $\sqrt{ }$ & $\sqrt{ }$ & $\times$ & $x$ & $x$ \\
\hline Respondent 7 & $\sqrt{ }$ & $\sqrt{ }$ & $\sqrt{ }$ & $\sqrt{ }$ & $\sqrt{ }$ & $\sqrt{ }$ & $\sqrt{ }$ & $\sqrt{ }$ & $\sqrt{ }$ & $\sqrt{ }$ \\
\hline Respondent 8 & $\sqrt{ }$ & $\sqrt{ }$ & $\sqrt{ }$ & $\sqrt{ }$ & $\sqrt{ }$ & $\sqrt{ }$ & $\sqrt{ }$ & $\sqrt{ }$ & $\sqrt{ }$ & $\sqrt{ }$ \\
\hline Respondent 9 & $\sqrt{ }$ & $\sqrt{ }$ & $\sqrt{ }$ & $\sqrt{ }$ & $\sqrt{ }$ & $\sqrt{ }$ & $\sqrt{ }$ & $\sqrt{ }$ & $\sqrt{ }$ & $\sqrt{ }$ \\
\hline Respondent 10 & $\sqrt{ }$ & $\sqrt{ }$ & $x$ & $x$ & $x$ & $\sqrt{ }$ & $\sqrt{ }$ & $\sqrt{ }$ & $\sqrt{ }$ & $\sqrt{ }$ \\
\hline Respondent 11 & $\sqrt{ }$ & $\sqrt{ }$ & $\sqrt{ }$ & $\sqrt{ }$ & $\sqrt{ }$ & $\sqrt{ }$ & $\sqrt{ }$ & $\sqrt{ }$ & $\sqrt{ }$ & $\sqrt{ }$ \\
\hline Respondent 12 & $\sqrt{ }$ & $\sqrt{ }$ & $\sqrt{ }$ & $\sqrt{ }$ & $\sqrt{ }$ & $\sqrt{ }$ & $\sqrt{ }$ & $x$ & $\sqrt{ }$ & $\sqrt{ }$ \\
\hline
\end{tabular}


Table 3 (cont). Choice of content areas to assist respondents in the achievement of project goals

\begin{tabular}{|l|c|c|c|c|c|c|c|c|c|c|}
\hline Respondent 13 & $\sqrt{ }$ & $\sqrt{ }$ & $\sqrt{ }$ & $\sqrt{ }$ & $\sqrt{ }$ & $\sqrt{ }$ & $\sqrt{ }$ & $\sqrt{ }$ & $\sqrt{ }$ & $\sqrt{ }$ \\
\hline Respondent 14 & $\sqrt{ }$ & $\sqrt{ }$ & $\times$ & $\sqrt{ }$ & $\sqrt{ }$ & $\sqrt{ }$ & $\sqrt{ }$ & $\times$ & $\sqrt{ }$ & $\times$ \\
\hline Respondent 15 & $\sqrt{ }$ & $\sqrt{ }$ & $\sqrt{ }$ & $\times$ & $\times$ & $\sqrt{ }$ & $\sqrt{ }$ & $\sqrt{ }$ & $\sqrt{ }$ & $\sqrt{ }$ \\
\hline Respondent 16 & $\sqrt{ }$ & $\sqrt{ }$ & $\sqrt{ }$ & $\sqrt{ }$ & $\sqrt{ }$ & $\times$ & $\sqrt{ }$ & $\sqrt{ }$ & $\sqrt{ }$ & $\sqrt{ }$ \\
\hline Respondent 17 & $\sqrt{ }$ & $\sqrt{ }$ & $\sqrt{ }$ & $\sqrt{ }$ & $\sqrt{ }$ & $\sqrt{ }$ & $\sqrt{ }$ & $\sqrt{ }$ & $\sqrt{ }$ & $\sqrt{ }$ \\
\hline Respondent 18 & $\sqrt{ }$ & $\sqrt{ }$ & $\sqrt{ }$ & $\sqrt{ }$ & $\sqrt{ }$ & $\sqrt{ }$ & $\sqrt{ }$ & $\sqrt{ }$ & $\sqrt{ }$ & $\sqrt{ }$ \\
\hline$\%$ Choise & $94 \%$ & $100 \%$ & $83 \%$ & $89 \%$ & $72 \%$ & $89 \%$ & $89 \%$ & $67 \%$ & $89 \%$ & $72 \%$ \\
\hline
\end{tabular}

Table 4. Proposal per official of special finance training required

\begin{tabular}{|l|l|}
\hline Respondent & \multicolumn{1}{|c|}{ Special training needs proposed } \\
\hline Respondent 1 & None \\
\hline Respondent 2 & None \\
\hline Respondent 3 & EPC financing model \\
\hline Respondent 4 & None \\
\hline Respondent 5 & BOT Public private partnership contracts \\
\hline Respondent 6 & None \\
\hline Respondent 7 & China exim bank EPC contract financial models \& PPP infrastructure concessions \\
\hline Respondent 8 & None \\
\hline Respondent 9 & Characteristics and legal framework of project special purpose vehicles \\
\hline Respondent 10 & Regulated asset base model (RAB) \\
\hline Respondent 11 & Value for money analysis for PPP Projects \\
\hline Respondent 12 & Preparation and structuring of banckable projects \\
\hline Respondent 13 & Structuring of cross boader donor funded projects \\
\hline Respondent 14 & Output performance based road contracts (OPRC) \\
\hline Respondent 15 & None \\
\hline Respondent 16 & Power station financing models \\
\hline Respondent 17 & None \\
\hline Respondent 18 & None \\
\hline
\end{tabular}

\section{Summary and recommendations}

This analysis has highlighted that Africa has infrastructure funding needs of $\$ 120 \mathrm{bn}$ with $95 \%$ of initiatives still in the concept and pre-feasibility stage. A significant component of Africa's infrastructure is domestically financed, with the central government budget being the main driver of infrastructure investment. It is, therefore, important to strengthen the finance and technical capacity of public sector officials to effectively manage the preparation, structuring, implementation and operations and maintenance of infrastructure. Africa's institutional, regulatory, and administrative reforms are only halfway along, but they are already proving their effect on operational efficiency. Infrastructure and skills development will provide a high competitive advantage for attracting capital flows and investment to the continent. In the quest to improve capacity, the officials have highlighted limited working knowledge of financial instruments, products and services such as viability gap finance and partial risk guarantees, as well as different financing models including fixed and floating interest rate borrowing from DFIs. All officials interviewed confirmed the importance of prioritizing finance training in the areas of selection, preparation and appraisal of investment projects. These aspects should inform and drive the content, prioritization and funding of governments, donors, private sector and NEPAD infrastructure delivery capacity building programs aimed at accelerating progress towards closing Africa's severe infrastructure gap.

Based on the analysis, the following recommendations may be articulated as an output of this study:

- Governments in Africa should conduct continuous skills needs assessment in order to keep abreast with the human resource capacity requirements for accelerated delivery of the different phases of the project cycle.

- Countries in the continent should budget and leverage funding for training to increase the pipeline of critical public sector finance skills required for infrastructure delivery.

- The training sponsored should entail a balance of theory and practice in order to enable the officials to hit the ground running.

- Countries in Africa plan a significant proportion of infrastructure regionally, but execute delivery nationally leading to delays and asymmetries.

- Integrated finance skills development will facilitate partnerships in regional infrastructure planning, structuring and delivery. 
- The integrated finance skills development also presents an opportunity for rationalizing and harmonizing continent wide finance infrastructure policies, standards and specifications in order to promote regional integration.
- This is in line with the main tenets of the Abuja Treaty of 1991 targeting the creation of an African economic community, with a common currency by 2023 and an African central bank by 2028 .

\section{References}

1. African Development Bank. (2013). Structured Finance. Conditions for Infrastructure Project Bonds in African Markets. Tunis.

2. Department for International Development. (2009). Review of Public Financial Management Reform Literature. Evaluation Report EV698. London.

3. Ecorys Academy. (2015). Matra Pre-Accession Training on rule of law (MATRA PATROL). Strengthening Government Institutional Capacity in the Area of the Rule of Law. Public Finance Management. The Hague.

4. Ernest \& Young. (2014). Africa Attractiveness Survey. Executing Growth. Ernest \& Young Global Limited. United Kingdom.

5. Ernest and Young. (2014). Bridging the Gap. Ensuring Execution on Large Infrastructure Projects in Africa. Ernest \& Young Global Limited. United Kingdom.

6. Finance Maps of World. (2015). World Finance, Finance Theory. Concepts of Public Finance. New York

7. Fourie, D.J. (2012). Good governance for cost effective financial management. Africa Journal of Public Affairs, Volume 5, Number 3, December 2012, pp. 70-71.

8. New Partnerships for Africa's Development. (2014). Programme for Infrastructure Development in Africa. Interconnecting, Integrating and transforming the continent. Addis Ababa.

9. New Partnership for Africa's Development. (2015). PIDA Service Delivery Mechanism Concept Note. An Innovative Response by The NEPAD Planning and Coordinating Agency to address Capacity Constraints at the Project Origination Stage for PIDA PAP Projects. Addis Ababa.

10. The DBSA Development fund. (2008). Siyenza Manje Infrastructure Implementation Programme. Unpublished Board Report. Midrand

11. The Development Bank of Southern Africa. (2004). Project Finance and Obtaining Sufficient Funding for the Successful Completion of your Project. Midrand.

12. The International Bank for Reconstruction and Development. (2010). Africa's Infrastructure. A time for transformation. The World Bank. Washington DC.

13. The World Bank (2013). Africa Overview. Washington DC.

14. The World Bank and PPIAF. (2013). Private Participation in Infrastructure Projects Database, Marina Bay Financial Center Tower 2, Singapore

15. The World Bank. (2015). Global Economic Prospects. Having Fiscal Space and Using it. Washington DC.

16. The World Economic Forum. (2014). African Strategic Infrastructure Initiative. Managing Transnational Infrastructure Programmes in Africa - Challenges and Best Practices.The Boston Consulting Group. Geneva. Switzerland.

17. The United Nations Capital Development Fund. (2014). Project Finance. Dar Es Salaam. Tanzania 